\title{
AROMATHERAPY CHARCOAL BRIQUETTES FROM COCONUT SHELL (COCOS NUCIFERA) WITH THE ADDITION OF LOCAL ORANGE PEEL WASTE (CITRUS AMBLYCARPA) AND AGARWOOD POWDER WASTE (AQUILARIA MALACCENSIS) AS AN INNOVATIONS OF WETLAND PRODUCT
}

\author{
Rahmadi Adi, Ulfah Diana, Sari Noor Mirad \\ Sugiani Putri Maulida, Student \\ Study Program of Forestry, Faculty of Forestry, University of Lambung Mangkurat, \\ South Kalimantan, Indonesia \\ *E-mail: arahmadi@ulm.ac.id
}

\begin{abstract}
Coconut shell aromatherapy charcoal briquettes with the addition of local orange peel powder and agarwood powder is an innovation to develop charcoal briquettes. The purpose of the study was to analyze the proximate test which included moisture content, ash content, volatile matter content, bound carbon content, heating value and density, knowing the best treatment and organoleptic tests. Completely Randomized Design (CRD) method was used for 5 treatments $\times 3$ replications with 15 samples. The best water content is found in treatment $A(50 \%$ coconut shell $+50 \%$ agarwood powder) of $5.5067 \%$ and meets the ASTM standard, which is a maximum water content of $6 \%$, the best ash content is also found in treatment $A(50 \%$ coconut shell $+50 \%$ gaharu sawdust) of $3.0600 \%$ and all treatments entered the ASTM standard max $8 \%$. The best value for volatile matter content of 54.9700 was obtained in treatment C $(50 \%$ coconut shell $+30 \%$ agarwood powder $+20 \%$ local orange peel powder) and for the bound carbon content the best value was found in treatment C worth $34.3933 \%$, all treatment of volatile matter content and bound carbon content did not meet ASTM standards, namely for volatile matter content of 19 sd $28 \%$ and $60 \%$ bound carbon content. Treatment A showed the best calorific value of $5043.3267 \mathrm{cal} / \mathrm{g}$, but did not meet the ASTM standard of $6500 \mathrm{cal} / \mathrm{g}$. All treatments for density have not been included in the ASTM standard with a standard value of $1 \mathrm{gr} / \mathrm{cm}^{3}$, the best density is in treatment $E(50 \%$ coconut shell $+50 \%$ local orange peel powder). The results of the organoleptic test showed that from 5 respondents who were selected said that treatment $A$ ( $50 \%$ coconut shell $+50 \%$ agarwood powder) began to smell aromatherapy at 30 seconds of burning charcoal briquettes with long ignition of briquettes to ashes for 26 minutes.
\end{abstract}

\section{KEY WORDS}

Coconut shell, agarwood powder, local orange peel powder, aromatherapy briquettes.

Currently, the scarcity of fossil energy is a crucial problem along with population growth in Indonesia, more than $90 \%$ of the world's energy needs in the market from fossil raw materials. To reduce the consumption of fossil fuels, humans are competing to make alternative fuels that are easily available in nature and do not damage the environment. One of the large energy content is in biomass which is used as an environmentally friendly alternative energy that can be renewed (Admaja, W. 2018).

Charcoal briquettes are solid fuels made from biomass that function as a substitute for kerosene. The use of charcoal briquettes is still limited only as a substitute for kerosene, but in the development of charcoal briquettes it can be used as aromatherapy charcoal briquettes that can be applied in the health and beauty fields.

Coconut is a plant that grows in wetlands. Indonesia is one of the largest coconut producers in the world, with the largest in Java, Kalimantan, Sumatra, Sulawesi and Irian Jaya (Santoso, 2009). Waste from coconut fruit is coconut shell which is generally used as daily fuel. To increase the economic value of coconut shells, one of them is made of charcoal briquettes so that it can overcome the problem of coconut shell waste. Maryono, et al (2013). Coconut shell waste reaches 360 thousand tons per year. 
In general, local oranges (limau kuit) are only used for their pulp, leaving orange peel waste. Local orange peel waste has an aroma that can be used as an aromatherapy ingredient. Orange peels still contain flavonoids and essential oils (Hoshino et al 2014). The essential oil in orange peel has a calming effect so it is commonly used in aromatherapy mixtures in the health sector (Rusliati, 2016).

In South Kalimantan there is a famous local orange or lime kuit which is one of the plants of local wisdom. According to Irwan et al 2019, the yield of fresh lime peel essential oil is $0.472 \%$ and the dry one is $0.483 \%$. The largest component content was limonene $62.90 \%$ for fresh skin samples and $63.97 \%$ for dry skin samples. Essential oils can also repel mosquitoes because they contain linalool, geraniol and eugenol.

Gaharu wood is included in the essential oil group, has a distinctive smell so it is used as raw material for perfumes, cosmetics, incense to preservatives in various accessories. The gaharu sawdust waste used in this study is of low quality which is used as raw material for the production of agarwood oil and for incense (Balfas, 2008).

In South Kalimantan, a lot of aloe vera powder waste is found in Banjar Regency (Martapura) which is a center for making handicrafts such as prayer beads, sticks, bracelets where agarwood powder waste has not been utilized optimally so that it can be used as aromatherapy. Low quality agarwood (kemedangan) has sesquiterpene compounds without hormones (Waluyo, KT. 2014).

The research objectives include: (1) Proximat test analysis of coconut shell aromatherapy charcoal briquettes which includes water content, ash content, volatile content, bound carbon content, calorific value and density, (2) Testing the best treatment of coconut shell aromatherapy charcoal briquettes with addition of local orange peel waste and agarwood sawdust waste, (3) Organoleptic test of coconut shell charcoal briquettes with the addition of local orange peel waste (limau kuit) and agarwood waste on several people who were sampled.

\section{MATERIALS AND METHODS OF RESEARCH}

The materials used for the manufacture of charcoal briquettes are coconut shell waste, orange peel and agarwood powder. The adhesive used is tapioca and the tool used is a biobriquette press. The method used was Completely Randomized Design (CRD) with 5 treatments $\times 3$ replications with a total sample of 15 units. Treatment $A$ ( $50 \%$ coconut shell + $50 \%$ agarwood powder), B (50\% head shell powder $+40 \%$ agarwood powder $+10 \%$ local orange peel powder), C (50\%) coconut shell powder $+30 \%$ agarwood powder $+20 \%$ bark powder local orange), D (50\% coconut shell powder $+10 \%$ agarwood powder $+40 \%$ local orange peel powder), E (50\% coconut shell powder $+50 \%$ local orange peel powder). One mold of charcoal briquettes contains 50 grams of raw materials.

The research procedure for making charcoal briquettes is starting from the process of composing coconut shells, refining coconut shell charcoal, mixing coconut shell charcoal powder materials with aromatherapy ingredients in the form of agarwood powder and local orange peel powder according to the predetermined composition, the next step is the application of adhesive. Tapioca is then mixed and molded for charcoal briquettes, as well as drying charcoal briquettes in an oven or in the hot sun, testing for charcoal briquettes includes moisture content, ash content, volatile matter content, bound carbon content, value of heatand density, and organoleptic tests.

The physical characteristics of the biobriquettes were measured using ASTM: 2002.

Value of Heat (ASTM D58-65-13):

$$
\mathrm{NK}=(\Delta \mathrm{t} \times \mathrm{W}) / \mathrm{Mbb}-\mathrm{B}
$$

Where: $\mathrm{NK}=$ calorific value $(\mathrm{Cal} / \mathrm{gr}) ; \mathrm{t}=$ mean temperature difference $\left({ }^{\circ} \mathrm{C}\right)$; $\mathrm{Mbb}=$ mass of fuel; $\mathrm{B}$ = iron wire heat correction (kalg-1).

Ash Content (ASTM D3175-11):

Ash content $=($ weight of ash $) /($ weight of sample $) \times 100 \%$ 
Moisture Content (ASTM D3302-12):

$$
\text { Moisture content }=(\text { BB-BKT }) / B K T \times 100 \%
$$

Where: $\mathrm{BB}=$ weight of ingredients before oven; BKT = weight after oven.

Density:

$$
\text { Density }=(\text { mass }(\mathrm{g}) /(\text { volume }(\mathrm{m} 3)
$$

Volatile Content (ASTM D3175-11):

$$
\text { Volatile }=(B-C) / W \times 100 \%
$$

Where: $B=$ sample weight after drying from the water content test $(\mathrm{g}) ; \mathrm{C}=$ sample weight after oven (g); $\mathrm{W}=$ sample weight before water content test $(\mathrm{g})$.

Bound Rate (ASTM 5142):

$$
\text { Bound content }=100-\text { (moisture content-volatile matter-ash content) }
$$

Furthermore, the ingredients for making aromatherapy in the form of gaharu wood powder are purchased from craftsmen making bracelets and tasbih which are then blended and local orange peel powder is made by means of local orange peels (limau kuit) thinly sliced, dried, and in a blender and also this local orange peel is made. essential oil by distillation).

Then the organoleptic test was carried out by smelling the aroma of aromatherapy charcoal briquettes to 5 respondents for 30 seconds - 15 minutes.

\section{RESULTS AND DISCUSSION}

The high and low average moisture content of aromatherapy charcoal briquettes is presented in Figure 1 below.

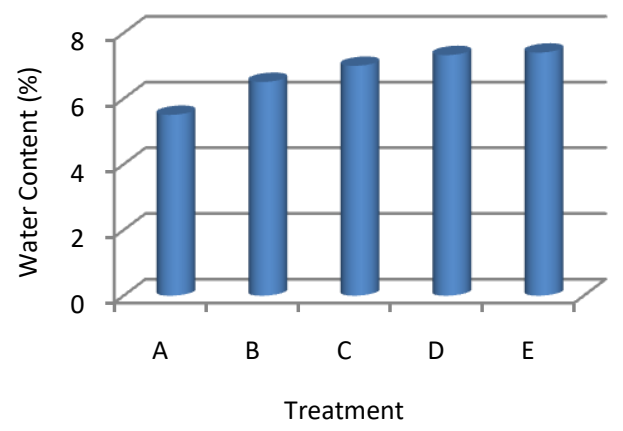

Figure 1 - Moisture content of coconut shell aromatherapy charcoal briquettes with the addition of agarwood powder and local orange peel powder

The range of water content of aromatherapy charcoal briquettes was not significantly different, namely $5.5067-7.4033 \%$.

The results of statistical testing of water content have a very significant effect on the addition of aromatherapy ingredients of agarwood powder and local orange peel powder.

The average test results showed that only A $(50 \%$ coconut shell powder $+50 \%$ agarwood sawdust) met the ASTM standard of a maximum of $6 \%$ while treatments $B, C, D$ and $E$ did not meet the ASTM standard, this is presumably due to the nature of the raw material. different. This is in line with the research of Nurmala Sari and Afiah (2007) which states that the raw material factor has a structure consisting of $6 \mathrm{C}$ atoms which form a 
hexagonal lattice which causes water vapor to be trapped inside and cannot evaporate when drying using an oven.

Variations in water content will affect the calorific value, the higher the water content value, the lower the calorific value. According to Haygreen and Bowyer (1989) in Muhammad et al (2013) this is because the heat stored in the briquettes is first used to remove water and then produces heat that can be used as combustion heat.

Briquettes will be difficult to ignite if they have a high water content and will produce smoke during combustion (Hutasoid, 2012). In addition, briquettes that contain a lot of water will be easily overgrown with fungus.

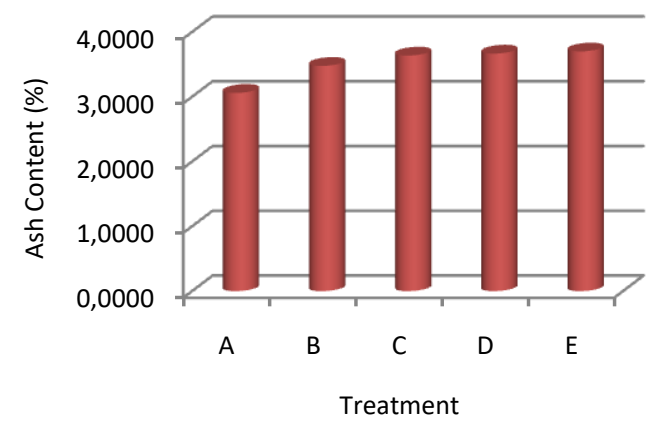

Figure 2 - Ash content of coconut shell aromatherapy charcoal briquettes with the addition of agarwood powder and local orange peel powder

Based on the graph above, the ash content value is not significant, which is in the range of $3.0600-3.700 \%$. The highest ash content was found in treatment $E(50 \%$ coconut shell powder $+50 \%$ local orange peel powder) and the lowest was found in treatment $A(50 \%$ coconut shell powder $+50 \%$ agarwood powder).

Variations in the average value of ash content that are not too significant are thought to be due to the uniform particle size of 45 mesh. The smaller the particle size, the lower the ash content. This is because the small particle size during the combustion process will be easily carried by the wind so that less ash is produced. According to Kurniawan (2019), the calorific value will be higher if the ash content is low.

The results of statistical tests showed that the addition of aromatherapy had no significant effect on the ash content value. All treatments met ASTM standards which required $8 \%$ ash content.

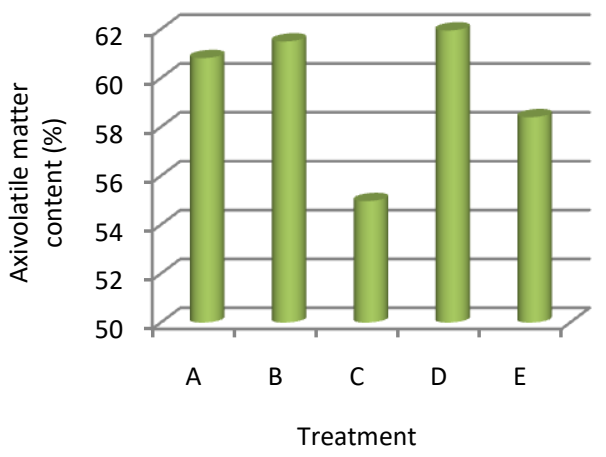

Figure 3 - The volatile matter content of coconut shell aromatherapy charcoal briquettes with the addition of agarwood powder and local orange peel powder

The highest volatile matter value was found in treatment D $(50 \%$ coconut shell powder $+10 \%$ agarwood powder $+40 \%$ local orange peel powder) which was $61.9533 \%$ and the lowest was found in treatment C $(50 \%$ coconut shell powder $+30 \%$ powder gaharu wood + $20 \%$ local orange peel powder) with a value of $54.9700 \%$.

All treatments for volatile matter did not meet ASTM standards, namely $19-28 \%$. 
The composition of the aromatherapy mixture of agarwood powder and local orange peel powder affects the high and low levels of volatile matter. High levels of volatile briquettes are also caused by coconut shell powder which has volatile substances (Iriany et al, 2016)). This is in line with the results of research by Kurniawan et al (2019) which stated that the levels of volatile matter are different for each material because they are influenced by volatile substances contained in these materials. High levels of volatile matter will cause a long flame that will produce a lot of smoke.

The results of statistical tests carried out showed that the addition of aromatherapy ingredients of agarwood powder and local orange peel powder had a significant effect on the value of volatile substances. According to Ristianingsih et al (2015) high levels of volatile matter are caused by high water content. This is due to the incomplete carbonization process. Furthermore, according to Nurmalasari et al (2017) high levels of volatile substances are also caused by temperature and time of writing. The greater the temperature at the time of writing, the content of the volatile substances produced will be lower.

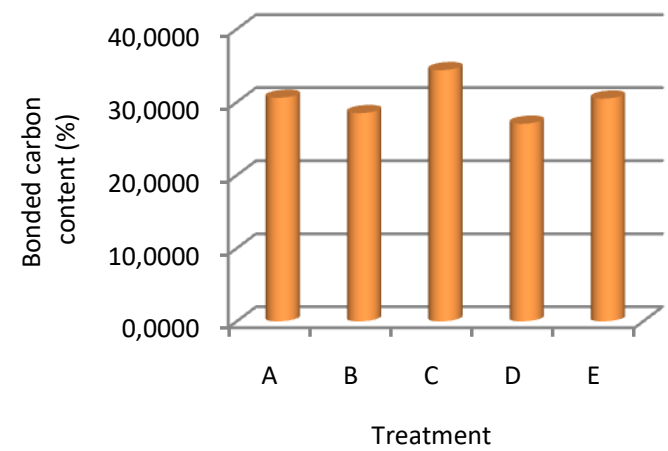

Figure 4 - Bonded carbon content of coconut shell aromatherapy charcoal briquettes with the addition of agarwood powder and local orange peel powder

The lowest bound carbon content was found in treatment $D(50 \%$ coconut shell powder $+10 \%$ agarwood powder $+40 \%$ local orange peel powder) which was $27,0533 \%$ and the highest was in treatment C $(50 \%$ coconut shell powder $+30 \%$ gaharu wood powder $+20 \%$ local orange peel powder) worth $34.3933 \%$.

Based on the results of statistical tests showed that the addition of agarwood powder and local orange peel powder had a significant effect on the results of the bound carbon content test. The calorific value is influenced by the value of the bound carbon content, if the bonded carbon value is high it will produce good quality charcoal briquettes (Muhammad et al, 2013).

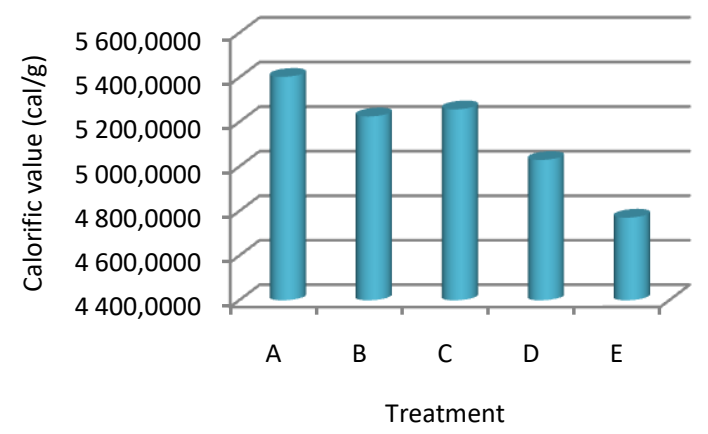

Figure 5 - Calorific value of coconut shell aromatherapy charcoal briquettes with the addition of agarwood powder and local orange peel powder

According to Sinurat (2011) the presence of bound carbon is influenced by the value of ash content and volatile matter content and water content. The bound carbon content will be 
high if the water content, ash content and volatile matter content are low.All treatments did not meet ASTM standards, namely $60 \%$.

The lowest value of heatwas found in treatment E $(50 \%$ coconut shell powder $+50 \%$ local orange peel powder) of $4,771.1667 \mathrm{cal} / \mathrm{g}$ and the highest of $5,403.3267 \mathrm{cal} / \mathrm{g}$ obtained from treatment $A$ ( $50 \%$ coconut shell powder $+50 \%$ agarwood powder).

All value of heattreatments did not meet ASTM standards, namely $6,500 \mathrm{cal} / \mathrm{g} . \mathrm{A}$ mixture of $50 \%$ coconut shell powder and $50 \%$ agarwood powder produces a high calorific value, the resulting calorific value is lower when compared to the research by Gunadi et al (2019) which produces a calorific value ranging from 5,411,900-7288,907 cal/g, further research by Saputra et al (2020) resulted in a value of heatranging from 3784.976-4174696 $\mathrm{cal} / \mathrm{g}$. According to Fajari (2012), the higher the value of heat, the higher the heat generated so that the combustion will take longer.

Statistical test results showed that the addition of agarwood powder aromatherapy and local orange peel powder had a significant effect on the calorific value. According to Kurniawan et al (2019) that the value of heatis influenced by bound carbon which changes its form to carbon dioxide by releasing a certain amount of energy. The best bound carbon content for charcoal and charcoal briquettes ranges from $50-95 \%$.

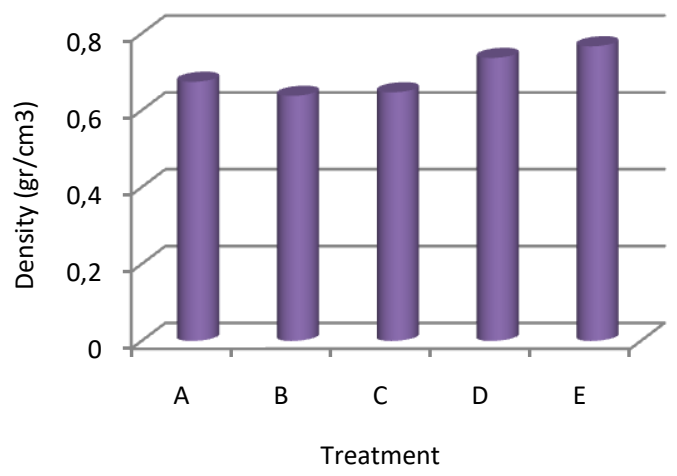

Figure 6 - Density of coconut shell aromatherapy charcoal briquettes with the addition of agarwood powder and local orange peel powder

The highest density value was found in a mixture of coconut shell charcoal briquettes and local orange peel powder (E) of $0.7669 \mathrm{gr} / \mathrm{cm}^{3}$ and the lowest was found in a mixture of $50 \%$ coconut shell charcoal briquettes $+40 \%$ agarwood powder $+10 \%$ local orange peel powder. (B) is $0.6380 \mathrm{gr} / \mathrm{cm}^{3}$.

According to Putri and Andasuryani (2017) the size of the density is determined by the size and uniformity of the particles that make up the briquettes. The particle size in this study is 45 mesh, relatively small so that the resulting particles are easier to become dense and dense and the number of empty cavities becomes less but causes the briquettes to be more difficult to burn and take longer time to be burned. This is in line with the research of Iriany et al (2016) which states that the particle size of 10 mesh with larger particles is more difficult to become denser than the 60 mesh treatment which is easier to become denser.

The high density is due to the combination of a mixture of coconut shell charcoal powder and local orange peel powder that is more unified, solid and strong and has a hard coconut shell texture. According to Putri and Andasuryani (2017) the density can be increased if the particle size used is smaller so that it can expand the bond between powders.

The results of statistical tests showed that the density value had a very significant effect on the addition of agarwood powder and local orange peel powder.All treatments for density did not meet the ASTM standard $1 \mathrm{~g} / \mathrm{cm}^{3}$.

The results of organoleptic testing of coconut shell aromatherapy charcoal briquettes with the addition of agarwood powder and local orange peel powder can be seen in Table 1 . 
Table 1 - Organoleptic Testing of Coconut Shell Aromatherapy Charcoal Briquettes with the Addition of Agarwood Powder and Local Orange Peel Powder

\begin{tabular}{|c|c|c|c|c|c|c|c|}
\hline \multirow{2}{*}{ Treatments } & \multirow{2}{*}{$\begin{array}{c}\text { Respondent's } \\
\text { name }\end{array}$} & \begin{tabular}{c} 
To \\
\cline { 3 - 7 }
\end{tabular} & $\begin{array}{c}1 \\
\text { Second }\end{array}$ & $\begin{array}{c}\text { Minutes } \\
\text { Minutes }\end{array}$ & $\begin{array}{c}10 \\
\text { Minutes }\end{array}$ & $\begin{array}{c}15 \\
\text { Minutes }\end{array}$ & $\begin{array}{c}\text { Time of Ignition of } \\
\text { Briquettes to Ash } \\
\text { (Minutes) }\end{array}$ \\
\hline A & Syamsudin & $\checkmark$ & $\checkmark$ & $\checkmark$ & $\checkmark$ & $\checkmark$ & 26 \\
B & Adytia & $\checkmark$ & $\checkmark$ & $\checkmark$ & $\checkmark$ & $\checkmark$ & 22 \\
C & Ayu Manipa & $\checkmark$ & $\checkmark$ & $\checkmark$ & $\checkmark$ & $\checkmark$ & 25 \\
D & Hafiz Ansari & $\checkmark$ & $\checkmark$ & $\checkmark$ & $\checkmark$ & $\checkmark$ & 20 \\
E & Muhammad & $\checkmark$ & $\checkmark$ & $\checkmark$ & $\checkmark$ & $\checkmark$ & 18 \\
\hline
\end{tabular}

Note: $\checkmark=$ smell; $-=$ no smell.

Of the 5 respondents who were selected, they said that under treatment A $(50 \%$ coconut shell $+50 \%$ agarwood powder) started to emit an aroma when burning lasted 30 seconds. And until the 15th minute, all respondents still smelled aromatherapy. The briquette ignition duration ranges from 18 to ash. 26 minutes.

\section{CONCLUSION}

The results of testing water content ranged from $5.5067-7.4033 \%$, ash content of $3.0600-3.7000 \%$, volatile matter content of $54.9700-61.5033 \%$, bound carbon content ranging from $27.0533-30.6100 \%$. The value of heat is $4,771.1667-5,403.3267 \mathrm{cal} / \mathrm{g}$ and the density is $0.6380-0.7669 \mathrm{~g} / \mathrm{cm}^{3}$.

The best treatment for water content was found in treatment $A(50 \%$ coconut shell + $50 \%$ agarwood powder) with ASTM $6 \%$ standard. The lowest ash content was also found in treatment $A(50 \%$ coconut shell $+50 \%$ agarwood powder) and all treatments entered the ASTM standard, the best volatile matter content was found in treatment $C(50 \%$ coconut shell $+0 \%$ agarwood powder $+20 \%$ powder). local orange peel) where all treatments did not meet the ASTM 19-28\% standard, the best bound carbon content was found in treatment C, which was $34.3933 \%$ and all treatments did not meet the ASTM $60 \%$ standard. The best value of heat was found in treatment $A(50 \%$ coconut shell $+50 \%$ agarwood powder) and all treatments did not meet the ASTM standard $6500 \mathrm{cal} / \mathrm{g}$, the best density was found in treatment $E(50 \%$ coconut shell $+50 \%$ local orange peel powder) and all treatments were not included in the ASTM $1 \mathrm{~g} / \mathrm{cm}^{3}$ standard.

The organoleptic test of treatment A was the best treatment. Of the 5 respondents who were appointed to start smelling aromatherapy when the burning went on for 30 seconds with the briquettes burning for 26 minutes to ashes.

\section{ACKNOWLEDGMENTS}

The authors would like to thank the University of Lambung Mangkurat which has funded this research with Research Contract No. contract 009.73/UN8.2/PL/2021

\section{REFERENCES}

1. Admaja, W. 2018. Pengaruh Campuran Buah Pinus dan Tinja Kambing dengan Perekat Tetes Tebu Terhadap Karakteristis Bio - Briket. Makalah Seminar. Jurusan Teknik Mesin Fakultas Teknologi Industri Nasional Malang.

2. Balfas, J. 2008. Kandungan Resin pada Kayu Gaharu Kualitas Rendah. Jurnal Penelitian Hasil Hutan Vol. 26 No. 1. Maret 2008: 97 - 105.

3. Fajari. I, 2012. Karakteristik Pembakaran Briket Arang Campuran Sekam Padi dan Serbuk Kayu serta Implementasinya sebagai Model Pembelajaran dengan LKS Kimia Berbasis Keterampilan Proses di SMAN 3 Lubuk Linggau Bengkulu. Tesis Pasca Sarjana Universitas Bengkulu. 
4. Gunadi. R.M, Mahdi. F.M, Sari.M.N 2019. Karakteristis Briket Arang Aromaterafi Dari, Kayu Gaharu. Jurnal Slyva Scienteae Vol.02 No.01.

5. Hanafiah, K.A, 2014. Rancangan Percobaan. Teori dan Aplikasi Edisi Ke - 3. Jakarta Utara. PT. Raja Grafindo Persada.

6. Hutasoit, Aripin. 2012. Briket Arang dari Pelepah Salak (Skripsi). Padang Fakultas Pertanian, Universitas Andalas.

7. Hoshino R, Wahyudiono, Machmudah S, Kanda H, Goto M. 2014. Stimultaneous Extraction of Water and Essential Oils from Citrus Leaves and Peels Using Liquified Dimethylether. Jounal Nutrition and Food Sciences 4(301): $1-5$.

8. Irwan, A, Rosydah, K. 2019. Potensi Minyak Atsiri dari Limau Kuit: Jeruk Lokal Kalimantan Selatan. Prosiding Seminar Nasional Lingkungan Lahan Basah Volume 4 No. 1 Halaman 197 - 202. April 2019.

9. Iriany, Sibarany. S. A. P. Melisa, 2016. Pengaruh Perbandingan Tempurung Kelapa dan Eceng Gondok serta Variasi Ukuran Partikel terhadap Karakteristik Briket. Jurnal Teknik Kimia USU, Vol 5 No 3.

10. Kurniawan. W. E, Rahman. M, Pemuda. K. R, 2019. Studi Karakteristik Briket Tempurung Kelapa dengan Berbagai Jenis Perekat. Buletin LOUPE Vol 15 No 1, Juli 2019. E - ISSN 2580 - 5274.

11. Maryono, Sudding dan Rahmawati, 2013. Pembuatan dan Analisis Mutu Briket Arang Tempurung Kelapa ditinjau dari KadarKanji. Jurnal Enemica 14(1)

12. Muhammad. A. R. D, Parnanto. R. H. N, Widadie. F, 2013. Kajian Peningkatan Mutu Briket Tempurung Kelapa dengan Alat Pengering Tipe Rak Berbahan Dasar Biomassa. Jurnal Teknologi Hasil Pertanian Vol VI No 1. Pebruari 2013.

13. Nurmalasari. N, Afiah. N, 2017. Briket Kulit Batang Sagu (Metroxylon sagu) Menggunakan Perekat Tapioka dan Ekstrak Daun Kapuk (Ceiba pentandra). Journal of Mathematics and Natural Science, 8(1), 1 - 10.

14. Putri, E. R dan Andasuryani, 2017. Studi Mutu Briket Arang dengan Bahan Baku Biomassa. Jurnal Teknologi Andalas, Vol 21 No 2. EISSN 2579 - 4019.

15. Ristianingsih. Y, Ulfa. A. K. S, Syafitri. R. 2015. Pengaruh Suhu dan Konsentrasi Perekat Terhadap Karakteristik Briket Bioarang Berbahan Baku Tandan Kosong Kelapa Sawit dengan Proses Pirolisis. Jurnal Konversi Vol 4, No 2.

16. Rusliati. T.R dan Zulhipri. Pengaruh Pengentalan Terhadap Mutu Atsiri Kulit Buah Jeruk Purut(Citrus Hystriy DC). Dalam sedia Deodoran. Jurnal Ke Farmasian Indonesia 2016

17. Santoso, Hieronymus. 2019. Air Kelapa, Limbah Penuh Khasiat. Mei 2009 http:/www.kompas.com. (Kompas Cyber Media).

18. Saputra.E, Violet, Sari.M.N.2020 Pengaruh Penambahan Serbuk Gaharu (Aquilaria Malaccensis) Terhadap Karakteritis Briket Arang Aromaterafi, Dari Limabah Kayu Campuran. Jurnal Sylva Scienteae Vo.03. No.4.

19. Sinurat, E. 2011. Studi Pemanfaatan Briket Kulit Jambu Mete dan Tongkol Jagung sebagai Bahan Bakar Alternatif. Tugas Akhir Fakultas Teknik Universitas Hasanuddin Makassar.

20. Waluyo, K.T. 2014. Peningkatan dan Pemanfaatan Mutu Gaharu Kualitas Rendah. Pusat Lit Bang Keteknikan Kehutanan dan Pengolaha Hasil Hutan. Bogor. 